\title{
Thermal Stability of Carbonic Anhydrase Immobilized Within Polyurethane Foam
}

\author{
Bora Kanbar and Ekrem Ozdemir \\ Dept. of Chemical Engineering, Izmir Institute of Technology, Gulbahce Campus, Urla, 35430-Izmir, Turkey
}

DOI 10.1002/btbr.452

Published online May 24, 2010 in Wiley Online Library (wileyonlinelibrary.com).

Thermal stability of carbonic anhydrase (CA) immobilized within polyurethane (PU) foam was investigated. The catalytic activity of the enzyme was estimated by using p-nitrophenyl acetate ( $p-N P A)$ as the substrate in tris buffer containing 10\% acetonitrile. The immobilized $C A$ was stable during the repeatable washings and stability tests over 45 days stored in tris buffer at ambient conditions indicating that the CA was covalently attached to the polyurethane (PU) foam by crosslinking. The immobilized CA was found to be $98 \%$ stable below $50^{\circ} \mathrm{C}$, whereas a drastic decrease was seen at temperatures between 50 and $60^{\circ} \mathrm{C}$. The optimum temperature for the immobilized CA was found to be $45^{\circ} \mathrm{C}$ and it lost its activity completely at $60^{\circ} \mathrm{C}$. Thermal deactivation energies for the free and immobilized $C A$ were estimated to be 29 and $86 \mathrm{kcal} / \mathrm{mol}$, respectively. The association of unfolded CA with the polymeric backbone chains of the PU foam was also addressed. It was concluded that the immobilized CA was highly stable at temperatures less than $50^{\circ} \mathrm{C}$ and could be used in biomimetic $\mathrm{CO}_{2}$ sequestration processes. () 2010 American Institute of Chemical Engineers Biotechnol. Prog., 26: 1474-1480, 2010

Keywords: carbonic anhydrase, $\mathrm{CO}_{2}$ sequestration, thermal stability, enzyme, immobilization, polyurethane foam

\section{Introduction}

The Carbonic anhydrase (CA) (EC 4.2.1.1) is a zinc containing metalloenzyme that mainly catalyzes the reversible hydration of carbon dioxide $\left(\mathrm{CO}_{2}\right) .{ }^{1}$ The CAs can also catalyze the dehydration of various aldehydes and the hydrolysis of esters, which are very useful for activity assays. ${ }^{2-4}$ There are at least five structural families of CA, characterized as $\alpha-, \beta-, \gamma-$, $\delta$ - , and $\varepsilon$-classes. ${ }^{5-7}$ These CAs are found in most eukaryotic and many microbial organisms. ${ }^{8-11}$ There are 16 different isozymes in mammals, and at least ten of them are human isozymes. ${ }^{12}$ The catalytic active site of the CAs consists of a zinc ion $\left(\mathrm{Zn}^{2+}\right)$ attached to three histidine residues. ${ }^{7}$ There are 18 lysine groups in the amino acid sequence of the CAs and most of them are at the surface of the enzyme. ${ }^{13}$ The lysines containing amine groups provide the enzyme an efficient immobilization. The mechanism of the hydration of the $\mathrm{CO}_{2}$ by the $\mathrm{CA}$ is initiated by a nucleophilic attack on the carbon atom of the $\mathrm{CO}_{2}$ by the zinc-bound $\mathrm{OH}$-group to produce bicarbonate, which is then displaced from the zinc by a water molecule. ${ }^{14}$ The diverse classes of the CA have shown different activities for $\mathrm{CO}_{2}$ and for other substrates. ${ }^{3-5,15-18}$

The CA has recently become important in the area of biological $\mathrm{CO}_{2}$ sequestration. Bond et al. ${ }^{19}$ developed an integrated system for biomimetic $\mathrm{CO}_{2}$ sequestration, which used the enzyme $\mathrm{CA}$ to accelerate the rate of $\mathrm{CO}_{2}$ hydration for the subsequent fixation into stable mineral carbonates. Mirjafari et al. $^{20}$ investigated the application of CA enzyme to

Correspondence concerning this article should be addressed to E. Ozdemir at ekremozdemir@iyte.edu.tr. enhance the hydration of $\mathrm{CO}_{2}$ in the solution. Liu et al. ${ }^{21}$ studied the precipitation of $\mathrm{CaCO}_{3}$ from produced waters in the presence of the CA enzyme. Using the free enzyme in solution has some disadvantages such that the stability of the enzyme is low, its repeatable usage is limited, and recovery from the reaction environment generally won't be possible. These disadvantages can be eliminated by immobilizing the enzyme within solid supports. Drevon et al. ${ }^{16}$ immobilized CA on coatings by covalent attachment; Liu et al. ${ }^{21}$ immobilized CA on chitosan-alganite beads by encapsulation; Jovica and $\mathrm{Kostic}^{22}$ immobilized CA within silica monoliths by sol-gel method; Cheng et al. ${ }^{23}$ immobilized CA within the poly(acrylic acid-co-acryamide) hydrogel by entrapment; and Hosseinkhani and Nemat-Gorgani ${ }^{24}$ immobilized CA on hydrophobic adsorbent of Sepharose 4B by adsorption. Although polyurethanes (PU) are widely used for immobilization of enzymes and cells, ${ }^{25-29}$ to our knowledge, the CA has not been immobilized within PU foam; until recently, the CA was immobilized within PU foam by crosslinking in our lab. ${ }^{30}$ It is important to know the thermal stability of the immobilized CA within the PU foam due to the process conditions during the biomimetic $\mathrm{CO}_{2}$ sequestration, especially when the $\mathrm{CO}_{2}$ is captured from the hot flue gases. Here, the thermal stability of the immobilized CA was reported.

\section{Materials and Methods}

\section{Materials}

CA from bovine erythrocytes (89\% pure in protein as dialyzed and lyophilized powder), para-nitrophenyl acetate (p- 
NPA), para-nitrophenol (p-NP) were purchased from SigmaAldrich. Acetonitrile $(99.9 \% \mathrm{v} / \mathrm{v})$, sodium hydroxide $(97 \% \mathrm{w} / \mathrm{w})$, hydrochloric acid $(35 \% \mathrm{v} / \mathrm{v})$ were purchased from Merck. Polyurethane prepolymer, HYPOL-2060, was a kind gift from Dow Chemical, Turkey.

\section{Immobilization of CA within PU Foam}

A sample of CA in powder form was dissolved in a $3 \mathrm{~mL}$ of distilled water (DI) and poured onto about $3 \mathrm{~g}$ of viscous HYPOL2060 prepolymer in a $50 \mathrm{~mL}$ falcon tube. ${ }^{30}$ The two phase system was mixed vigorously for $30 \mathrm{sec}$ by a drill with a hand-made mixer blade to achieve a homogeneous distribution of the enzyme within the prepolymer. The level of the white polymeric solution started to increase as a result of a $\mathrm{CO}_{2}$ release during the polymerization. The level and the polymerization were settled in 2-3 min. After completion of the enzyme immobilization, a piece of foam was cut at the middle of the whole product and characterized for $\mathrm{CA}$ enzyme activity.

\section{Enzyme activity assay}

The activities of the free and immobilized CA were estimated at $25^{\circ} \mathrm{C}$. For the free $\mathrm{CA}$, the activity assay was performed in a $1 \mathrm{~mL}$ UV cuvette, in which the reaction mixture was prepared with $0.8 \mathrm{~mL}$ Tris buffer $(50 \mathrm{mM}, \mathrm{pH}=7.5)$, $0.1 \mathrm{~mL}$ substrate solution ( $\mathrm{p}-\mathrm{NPA}$ dissolved in acetonitrile) and $0.1 \mathrm{~mL}$ enzyme solution (CA in tris buffer). This solution was mixed in the cuvette by the help of the micropipette. The final mixture contained $10 \%$ of acetonitrile. The enzyme activity was measured in UV/VIS spectrometer at $400 \mathrm{~nm}$ for $3 \mathrm{~min}$. Blank experiments were also conducted for each assay solution to estimate the self-dissociation of $\mathrm{p}$ NPA, which was then subtracted from the enzymatic rates to determine the enzyme activity.

For the immobilized CA, a $10 \mathrm{~mL}$ of substrate solution was prepared by mixing a $1 \mathrm{~mL}$ of p-NPA solution (p-NPA dissolved in acetonitrile) and a $9 \mathrm{~mL}$ of Tris buffer $(50 \mathrm{mM}$, $\mathrm{pH}=7.5$ ) in a $30 \mathrm{~mL}$ vial by a magnetic stirrer. In a separate container, a piece of the CA immobilized PU foam was washed by squeezing several times in the tris buffer and let it to soak in the buffer. The reaction was started when the foam was added into the prepared substrate solution. A 1 $\mathrm{mL}$ of sample was taken from the reaction mixture, measured its absorbance in UV/Vis spectrometer at $400 \mathrm{~nm}$ for a short time, and poured back into the reaction mixture. This procedure was repeated at $1 \mathrm{~min}$ interval for 25-30 min. At the end of the assay, the foam was washed and dried at $80^{\circ} \mathrm{C}$ under vacuum, and then weighted for analysis.

\section{Stability and reuse capacity of the immobilized CA}

The stability and reuse capacity of the immobilized CA was estimated by using the same piece of foam sample. The piece of the CA immobilized foam sample was cut at the middle of the whole product and stored in the tris buffer (50 $\mathrm{mM}, \mathrm{pH}=7.5$ ) at room temperature. The foam sample was washed by squeezing several times in the tris buffer and the activity of this sample was estimated with the immobilized enzyme activity assay. At the end of the enzyme activity, the foam was washed again and stored until the next activity assay. The activity tests were repeated in every 3-4 days over 45 days with the same concentration of the p-NPA.

\section{Effect of reaction temperature on catalytic activity of immobilized CA}

The activity of the immobilized CA was estimated at various reaction temperatures. The immobilized enzyme activity assay was performed in a glass jacket reactor containing a $20 \mathrm{~mL}$ of total reaction mixture, including $90 \%$ of tris buffer and $10 \%$ of p-NPA solution. The temperature in the reactor was maintained at $18,30,40,50,60^{\circ} \mathrm{C}$ by a thermal circulator. Before the experiment, the buffer solution was heated to the specified temperature. A $1 \mathrm{~mL}$ of reaction mixture was taken into a UV-cuvette, measured its absorbance, and returned back to the reactor at every 1 min interval for 25$30 \mathrm{~min}$. The self-dissociation of p-NPA was also estimated at each temperature and the background signal was corrected for the enzyme activity.

\section{Thermal stability of free and immobilized CA}

For the thermal stability of the free CA, a sample of CA solution in tris buffer $(50 \mathrm{mM}, \mathrm{pH}=7.5)$ was incubated in a jacketed glass reactor at constant specified temperature by stirring with a magnetic stirrer for up to $120 \mathrm{~min}$. To prevent the evaporation of the enzyme solution, the reactor was closed with a rubber stopper. In about every $20 \mathrm{~min}, 0.1 \mathrm{~mL}$ of enzyme solution was taken from the reactor and assayed at $25^{\circ} \mathrm{C}$ for the free $\mathrm{CA}$ activity. This procedure was repeated for each specified incubation temperatures.

For the thermal stability of the immobilized CA, a piece of CA immobilized foam was incubated at the desired temperature for $2 \mathrm{~h}$ in a glass jacket reactor by stirring by a magnetic stir bar. In about $20 \mathrm{~min}$ intervals, the foam sample was taken out from the constant temperature water bath and assayed at $25^{\circ} \mathrm{C}$ for the immobilized CA activity in a $2.5 \mathrm{mM}$ of $\mathrm{p}$-NPA solution in the presence of $10 \%$ of acetonitrile. During this time, a $1 \mathrm{~mL}$ of sample was taken from the reaction mixture, measured its absorbance in UV/Vis spectrometer at $400 \mathrm{~nm}$ for a short time, and poured back into the reaction mixture. This procedure was repeated at $1 \mathrm{~min}$ interval for 25-30 $\mathrm{min}$. After the activity assay was complete, the sample was then washed by squeezing several times in fresh tris buffer and returned back to the incubation reactor at its desired temperature. This procedure was repeated for other samples used for other temperatures specified. At the end of the tests, the foam samples were dried at $80^{\circ} \mathrm{C}$ in vacuum oven for $150 \mathrm{~min}$ to determine their dry weight for analysis.

\section{Results and Discussion}

\section{Immobilization of CA within PU Foam}

The CA was immobilized within the polyurethane foam by mixing a $1: 1$ of the HYPOL prepolymer with the DI water containing dissolved CA. The chemical structure of the HYPOL prepolymer is shown in Scheme $1 \mathrm{a} .{ }^{31}$ The HYPOL has a hydrophilic structure and its ends are terminated with the isocyanate groups. ${ }^{25,29}$ According to Scheme $1 \mathrm{~b}$, the enzymes can be immobilized within the PU foam through their amine groups because the reaction rate constant between the isocyanate and amine is the highest. ${ }^{32}$. According to Scheme 1c, the isocyanate groups react with the water converting the isocyanate groups into amines by releasing $\mathrm{CO}_{2}$ gas. According to Scheme 1d, the produced amine groups react rapidly with the remaining isocyanate groups 


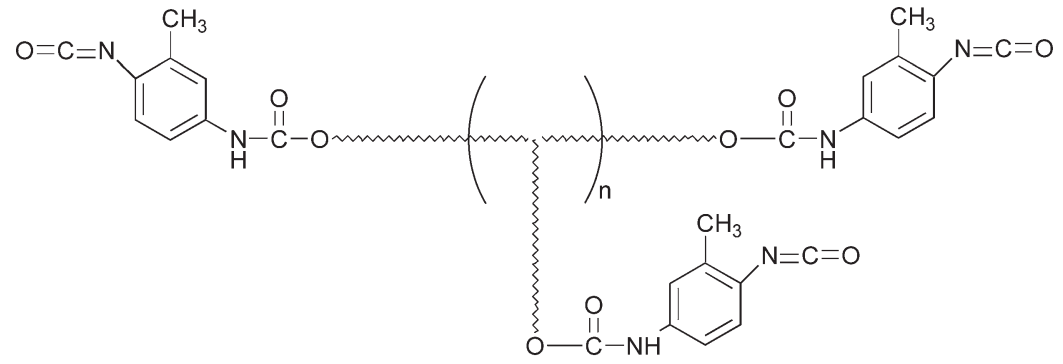<smiles>[R]c1ccc(NC(=O)N=CNC(=O)Nc2ccc([R])cc2C)c(C)c1</smiles><smiles>[R]c1ccc(N=C=O)c(C)c1</smiles><smiles>[R]c1ccc(N=C=O)c(C)c1</smiles>

Scheme 1. Immobilization of enzymes within polyurethane foam.

(a) HYPOL prepolymer capped with isocyanate end groups, (b) crosslinking of enzymes, (c) CO2 generation, (d) crosslinking for a porous foam formation.

forming a crosslinked polymeric material. The $\mathrm{CO}_{2}$ gas serves as creating large pores in the polymeric networks.

The picture of the polyurethane foam as a support for the enzyme immobilization is shown in Figure 1a. Figure $1 \mathrm{~b}$ shows the SEM image of the porous structure of the CA immobilized PU foam, and Figure 1c shows the SEM image of the surface of the polymeric backbone of the CA immobilized PU foam. As can be seen in the figure, the pore sizes in the PU foam is less than $500 \mu \mathrm{m}$. The enzyme is crosslinked within the polymeric network and active in the structure, although it can not be seen due to its small size of about $4.5 \mathrm{~nm} .{ }^{33}$ The porous structure of the PU foam enables the substrates and the products to diffuse in and out of the polymeric network. Figure 2 shows the TGA analysis of the PU foam. Although the PU sample was dried at $80^{\circ} \mathrm{C}$ before the TGA analysis, it captured about $12 \%$ of moisture once it was exposed to the atmosphere due to its highly hydrophilic nature. It can be seen from the figure that the PU foam is thermally stable at temperatures up to $280^{\circ} \mathrm{C}$. The hydrophilic nature, its thermal stability, and the flexible structure of the PU foam make it a suitable matrix for the enzyme immobilization.

\section{Activities of the free and immobilized CA}

The activities for the free and immobilized CA were estimated using p-NPA as the substrate in tris buffer $(50 \mathrm{mM}$, $\mathrm{pH}=7.5)$ in the presence of $10 \%(\mathrm{v} / \mathrm{v})$ of acetonitrile. The concentration of the p-NPA could only be used up to 3.1 $\mathrm{mM}$ due to its low solubility in the aqueous phase. Figure 3 shows the hydrolysis rate for the free and immobilized CA. The lines are the curve fit of experimental data to the Michealis-Menten Equation, where the kinetic constants were obtained from the Lineweaver-Burk equation. ${ }^{34}$ The ki- netic constants were calculated for the free CA as $k_{\text {cat }}=$ $2.02 \mathrm{sec}^{-1}, \quad K_{\mathrm{m}}=12.2 \mathrm{mM}$, and $k_{\mathrm{cat}} / K_{\mathrm{m}}=166.4$ $\mathrm{M}^{-1} \mathrm{sec}^{-1} .^{30}$ Because the amount of enzyme actually immobilized within the PU foam were not known accurately, the $k_{\text {cat }}$ and $k_{\text {cat }} / K_{\mathrm{m}}$ values could not be determined for the immobilized CA. Therefore, the $K_{\mathrm{m}}$ value for the immobilized $\mathrm{CA}$ was found to be $9.6 \mathrm{mM}$. These values are in good agreement with the literature data. 30,35

\section{Stability and reuse capacity of the immobilized $C A$}

A slice of the CA immobilized PU foam was incubated in tris buffer $(50 \mathrm{mM}, \mathrm{pH}=7.5)$ at room temperature and its catalytic activity was estimated. When the assay was completed, the same piece of foam was washed and stored again at the same conditions until the following assay. Figure 4 shows the stability and the reuse capacity of the immobilized CA in PU foam. As shown in the figure, the immobilized CA was exhibited a $100 \%$ of its activity in its repetitive use. This behavior has two outcomes: The first one is that the immobilized CA did not leach out over subsequent washings; and, the other is that the immobilized CA maintained a $100 \%$ of its activity over 45 days when stored within aqueous media. This indicated that the CA has become part of the PU foam and maintained its activity within the flexible structure of the PU foam. It can easily be seen that the immobilized CA is a stable biocatalyst, which can be used again and again in industrial applications.

\section{Immobilized CA activity with temperature}

The activity of immobilized CA was measured at various temperatures as shown in Figure 5. The self-hydrolysis rate 

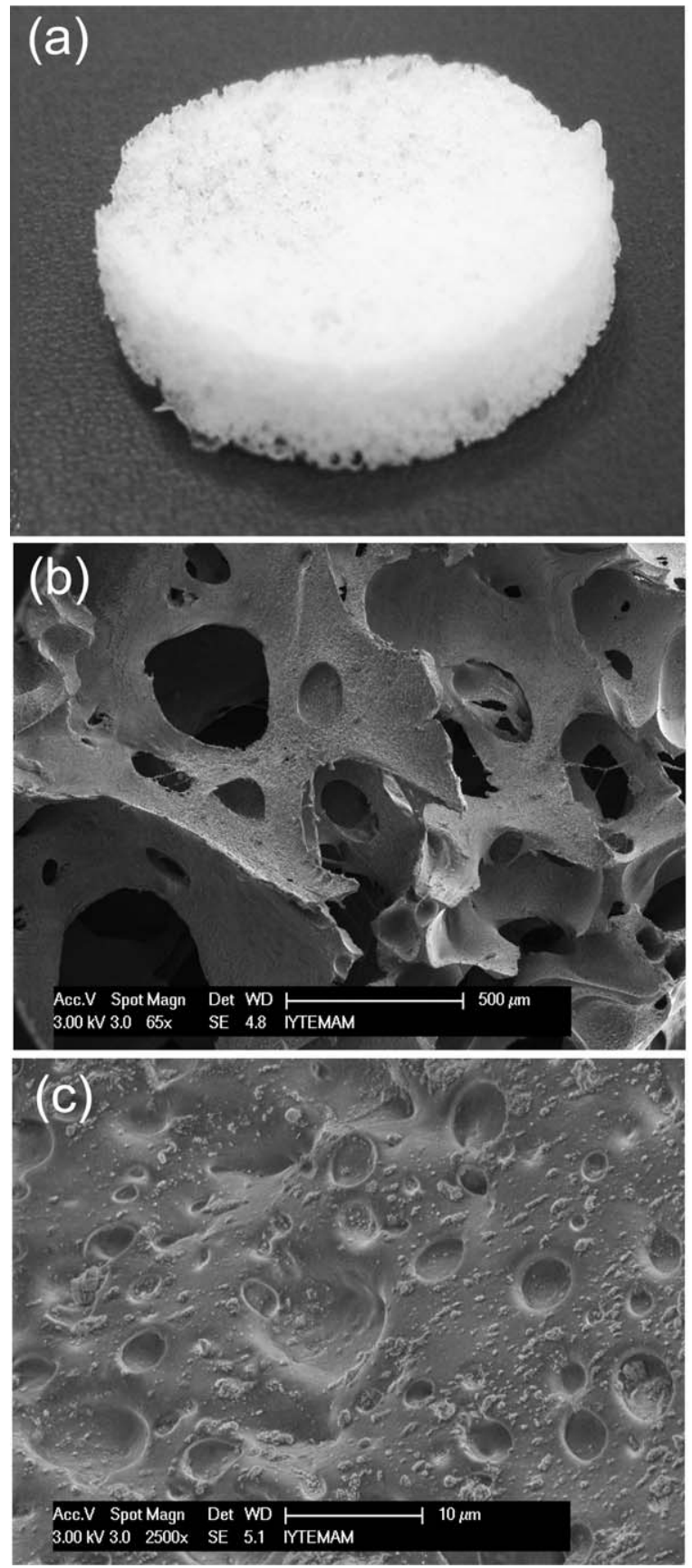

Figure 1. (a) A picture of CA immobilized PU foam (b) SEM image of CA immobilized PU foam (c) SEM image of the surface of CA immobilized PU foam.

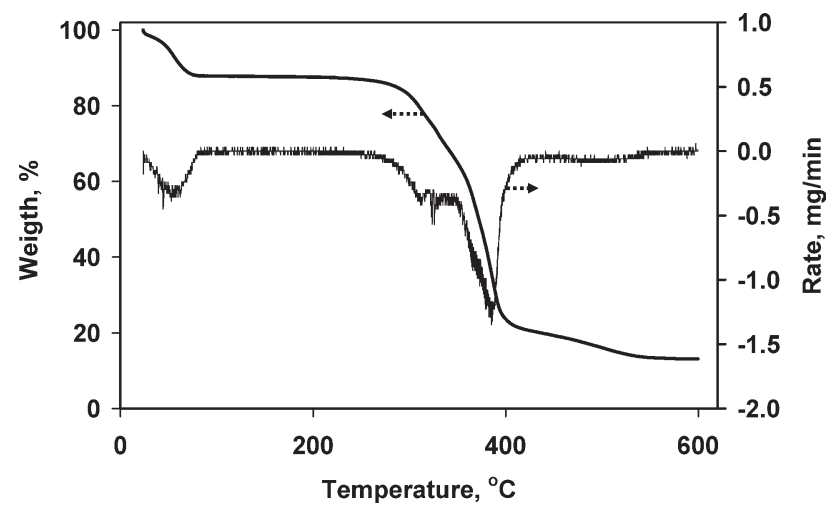

Figure 2. Thermal gravimetric analysis (TGA) of the PU foam.

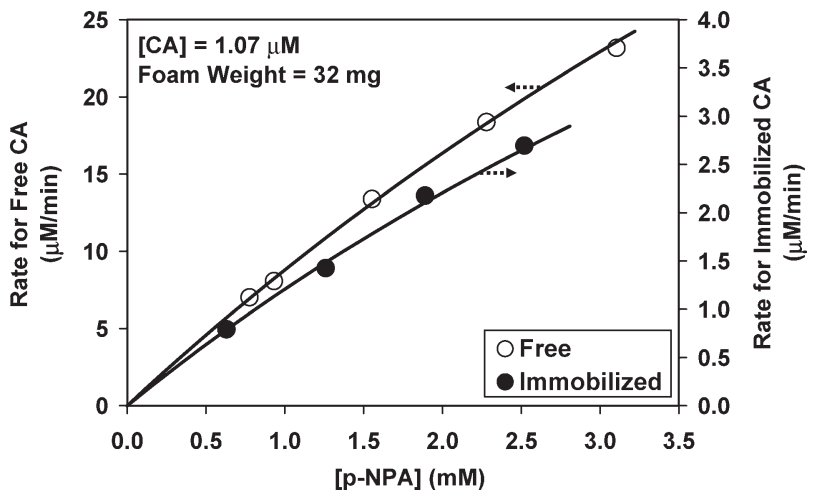

Figure 3. Catalytic activity for the free and immobilized CA within PU foam.

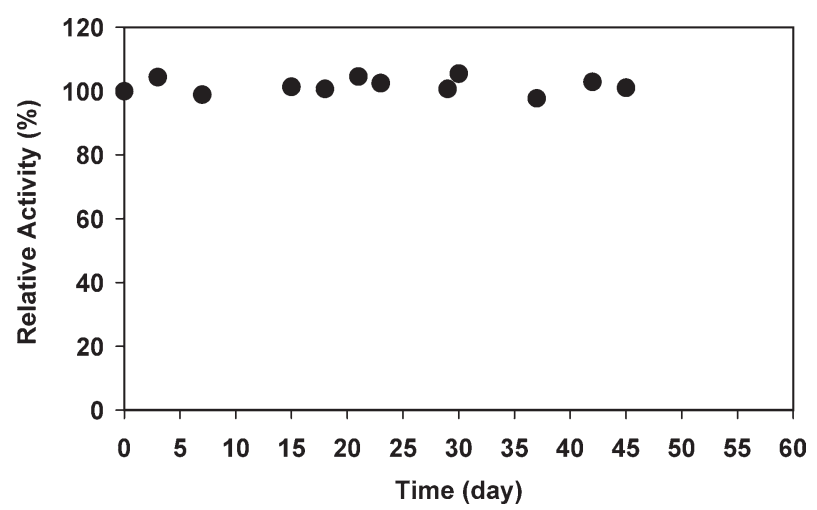

Figure 4. Stability and reuse capacity of the CA immobilized PU foam.

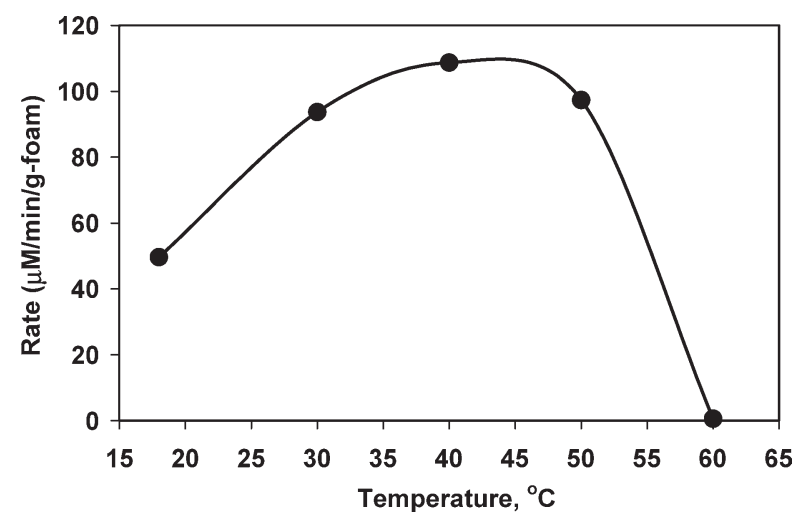

Figure 5. Temperature profile of the immobilized CA within PU foam.

was also estimated for the p-NPA as the substrate for the specified temperature and subtracted from the overall rate to obtain the actual activity at that temperature indicated. As shown in the figure, the activity of immobilized CA increases with temperature up to $40^{\circ} \mathrm{C}$. At temperatures between 30 and $50^{\circ} \mathrm{C}$, little deviation was observed for the activity of the immobilized CA. Here, the optimum immobilized CA activity was obtained at temperature about $45^{\circ} \mathrm{C}$. At temperature above $50^{\circ} \mathrm{C}$, the activity of the immobilized CA began to decrease, and all enzyme activity was lost at $60^{\circ} \mathrm{C}$.

\section{Thermal stability of the free and immobilized $C A$}

The thermal stabilities of the free and immobilized CA were estimated after incubating in tris buffer $(50 \mathrm{mM}, \mathrm{pH}=$ 
(a)

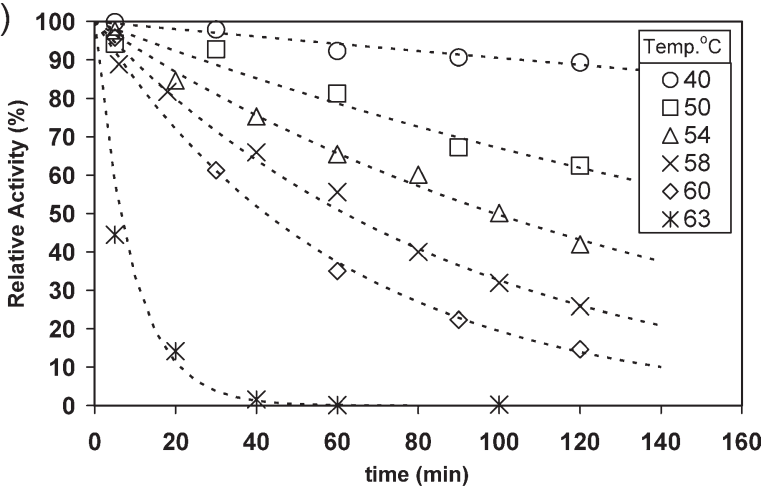

(b)

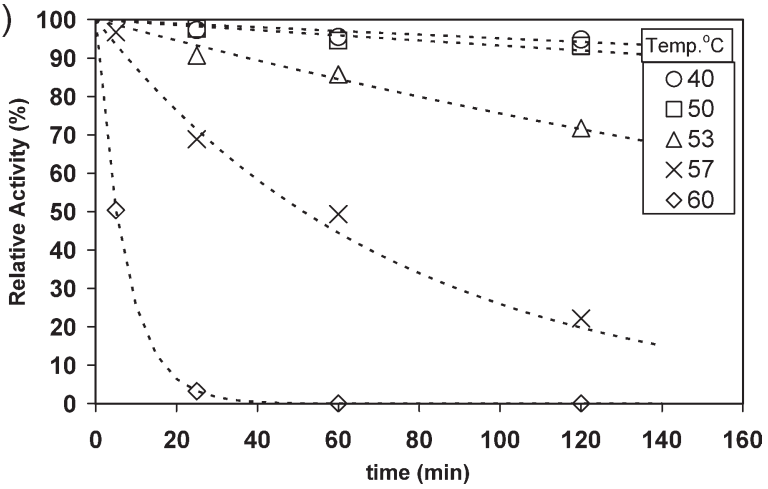

Figure 6. Heat inactivation curve for (a) free CA and (b) immobilized CA.
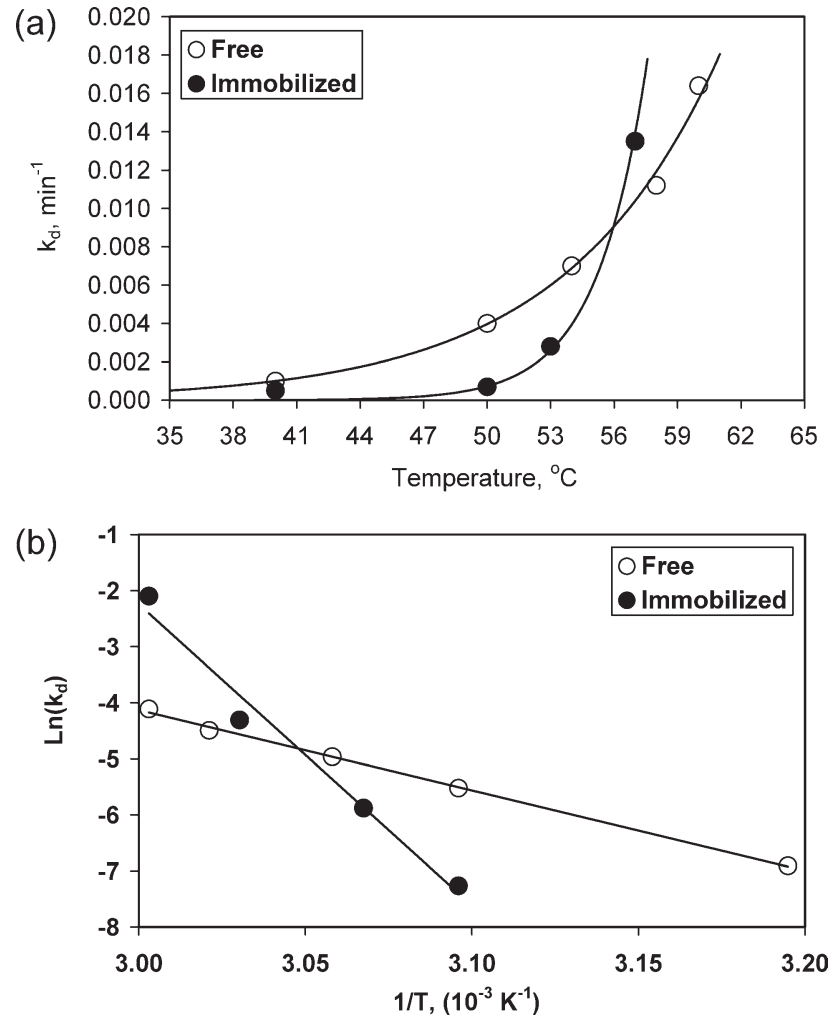

Figure 7. Thermal denaturation constant for the free and immobilized CA within PU foam, (b) the Arhenious plot for the denaturation constants of the free and immobilized CA.

7.5) at specified temperatures. The activity of the free CA was estimated by the free enzyme assay and the activity of the immobilized CA was estimated by the immobilized enzyme assay. Different from the free CA, the foam sample with the immobilized CA was returned back to the incubation reactor after the activity assay. Figure 6 shows the heat inactivation curves for the free and immobilized CA at different incubation temperatures. Here, the time interval of about 25-30 min. was not included for the immobilized CA for the activity determination assay. In the figure, points show the experimental data and lines show the first-order deactivation rate model $^{34}$ which can be given as;

$$
-\frac{\mathrm{d}[E]}{\mathrm{d} t}=k_{\mathrm{d}}[E]
$$

where $[E]$ is enzyme concentration at any time and $k_{\mathrm{d}}$ is the enzyme denaturation rate constant. Or, if active enzyme concentration is directly proportional to the rate of reaction, as it is the case here for the same substrate concentration, it can be given as;

$$
\ln \left(\frac{\text { Rate }}{\text { Rate }_{\mathrm{o}}}\right)=-k_{\mathrm{d}} t
$$

As can be seen in the figure, the free CA preserved almost $90 \%$ of its stability at the end of $120 \mathrm{~min}$ at $40^{\circ} \mathrm{C}$. When the incubation temperature was increased, the free enzyme began to lose its activity dramatically. At temperatures above $63^{\circ} \mathrm{C}$, the free CA lost its activity completely in $40 \mathrm{~min}$. On the other hand, the immobilized CA was very stable up to $50^{\circ} \mathrm{C}$. At temperatures above $50^{\circ} \mathrm{C}$, the immobilized $\mathrm{CA}$ began to lose its activity. The immobilized CA lost its activity completely in $20 \mathrm{~min}$ at incubation temperature of $60^{\circ} \mathrm{C}$.

When comparing Figure 6 with Figure 5, in fact, the activity of the CA should have been lost at temperatures higher than $60^{\circ} \mathrm{C}$. However, the free CA is still $35 \%$ active at $60^{\circ} \mathrm{C}$ whereas the immobilized CA has lost all of its activity at $60^{\circ} \mathrm{C}$ in a short time. This behavior can be related to the protein folding and stability characteristics. ${ }^{24,33,36,37}$ As shown in Eq. 3, the native CA (N) unfolds in two unfolding transitions, called the first transition, or a stable molten globule intermediate (I), and a second unfolding transition, or unfolded state in various forms $\left(\mathrm{U}_{\mathrm{i}}\right) .^{33,38}$ For the free enzyme, part of its activity was recovered at the assay condition of $25^{\circ} \mathrm{C}$, after its conformation was changed and became inactive at higher temperatures. For the immobilized enzyme, this was not the case where once the enzyme was unfolded at temperatures higher than $60^{\circ} \mathrm{C}$; it could not recover its activity at the assay temperature of $25^{\circ} \mathrm{C}$, probably due to the association of unfolded CA with the hydrophilic surface of the PU foam. ${ }^{24,39,40}$

$$
\mathrm{N} \rightleftarrows \mathrm{I} \rightleftarrows \mathrm{U}_{\mathrm{i}}
$$

Slope of $\ln \left(\right.$ Rate $\left._{\text {Rate }}\right)$ vs. time plot yields denaturation rate constant, $k_{\mathrm{d}}$, and the deactivation energy for the enzyme $\left(E_{\mathrm{d}}\right)$ can be estimated from the typical Arrhenius equation ${ }^{34}$ :

$$
k_{\mathrm{d}}=A_{\mathrm{d}} \mathrm{e}^{-E_{\mathrm{d}} / R T}
$$

and,

$$
\ln \left(k_{\mathrm{d}}\right)=\ln \left(A_{\mathrm{d}}\right)-\frac{E_{\mathrm{d}}}{R}\left(\frac{1}{T}\right)
$$

Figure 7 shows the estimated thermal denaturation constants and the Arrhenius plot for the free and immobilized CA. It can be seen from Figure $7 \mathrm{a}$ that both the denaturation constants for the free and immobilized CA increase 


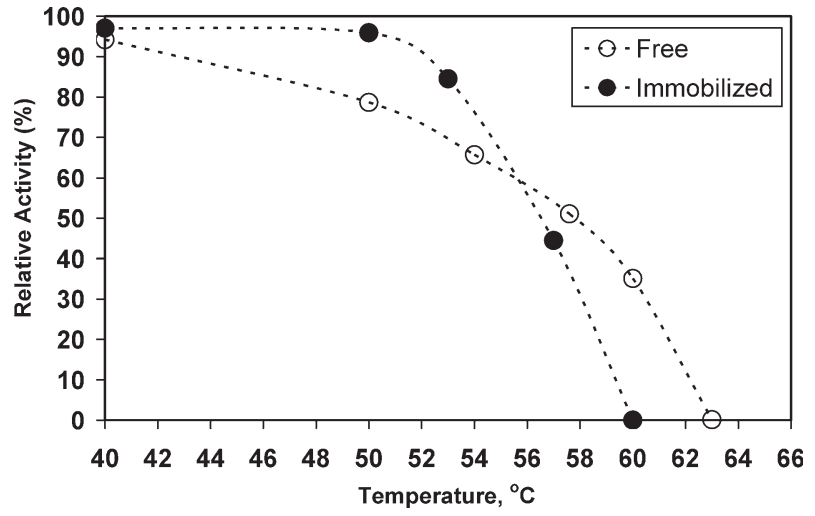

Figure 8. The remaining relative activity for the free and immobilized $\mathrm{CA}$ after $1 \mathrm{~h}$ incubation at constant temperature.

exponentially with temperature. The thermal denaturation constants for the free CA were higher than those for the immobilized $\mathrm{CA}$ at temperature below $56^{\circ} \mathrm{C}$ and they were lower at higher temperatures than $56^{\circ} \mathrm{C}$. The deactivation energies $\left(E_{\mathrm{d}}\right)$ for the free and immobilized CA were estimated from the slopes of $\ln \left(k_{\mathrm{d}}\right)$ vs. $1 / T$ plots as shown in Figure $7 \mathrm{~b}$. The deactivation energy was calculated as $29 \mathrm{kcal} / \mathrm{mol}$ for the free CA and 86 $\mathrm{kcal} / \mathrm{mol}$ for immobilized CA. The deactivation energy for the immobilized CA is higher almost three times than the deactivation energy for the free CA. The deactivation energies for the free and immobilized CA indicated that the immobilized CA was more stable than the free enzyme. However, this is only true at temperatures lower than $56^{\circ} \mathrm{C}$. When the temperature is higher than $56^{\circ} \mathrm{C}$, the immobilized CA loses its activity faster than the free form. This can be clearly seen in Figure 8, which shows the thermal stability for the free and immobilized CA at the end of 1 $\mathrm{h}$ of incubation at various temperatures. As shown in the figure, the activity for the free enzyme seems to decrease continuously. However, the activity for the immobilized CA was stable up to $50^{\circ} \mathrm{C}$ and started to decrease as the temperature was increased further. While the free $\mathrm{CA}$ lost its activity at $63^{\circ} \mathrm{C}$, the immobilized CA lost its activity at $60^{\circ} \mathrm{C}$, at which the free $\mathrm{CA}$ was active at about $35 \%$.

The activity regaining for the free $\mathrm{CA}$ is significant comparing to that for the immobilized $\mathrm{CA}$ at the incubation temperature of $60^{\circ} \mathrm{C}$. Considering Eq. 3, enzymes would undergo an unfolding transition at higher temperatures and could lose some of its activity. However, when the temperature was reduced, the enzyme can refold to some degree and regain some of its activity. Here, as shown in Figure 5, the activity loss for the free CA was only $5 \%$ at $40^{\circ} \mathrm{C}, 20 \%$ at $50^{\circ} \mathrm{C}, 35$ $\%$ at $58^{\circ} \mathrm{C}, 50 \%$ at $58^{\circ} \mathrm{C}, 65 \%$ at $60^{\circ} \mathrm{C}$, and inactive at $63^{\circ} \mathrm{C}$. On the other hand, the immobilized CA was stable up to temperatures of $50^{\circ} \mathrm{C}$, indicating that the stability of the immobilized CA was enhanced very much when immobilized within the PU foam by crosslinking. The immobilized CA recovered almost all of its activity at lower temperatures of less than $50^{\circ} \mathrm{C}$ even though it would undergo any unfolding transition. On the other hand, when the incubation temperature was increased, once unfolded, the immobilized CA could not recover its activity as much as that for the free $\mathrm{CA}$ primarily due to the possible association of the immobilized enzyme with the backbone polymeric chains of the PU foam. Therefore, while immobilized CA totally lost its activity at $60^{\circ} \mathrm{C}$, the free enzyme could recover about $35 \%$ of its activity when temperature was reduced to the assay temperature of $25^{\circ} \mathrm{C}$.

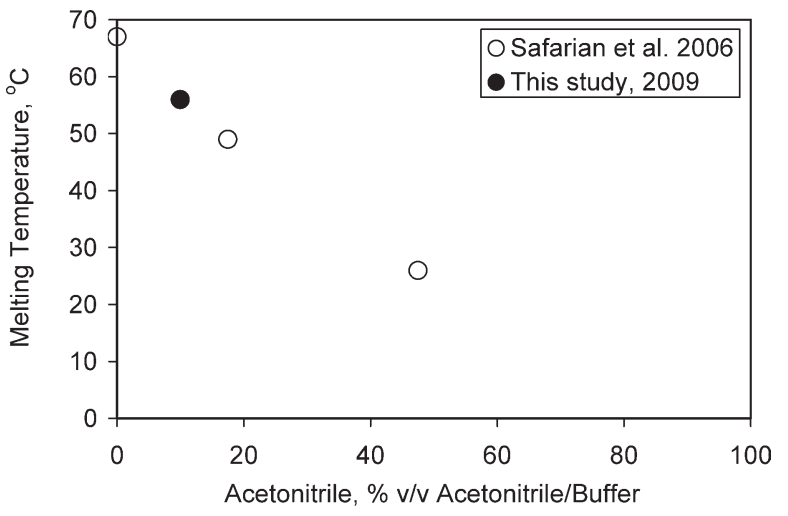

Figure 9. Melting temperature for $\mathrm{CA}$ in the presence of acetonitrile.

The melting temperature, which is the temperature when the relative activity for the enzyme was reduced to $50 \%$ after $60 \mathrm{~min}$, was found to be $58^{\circ} \mathrm{C}$ for the free CA and $57^{\circ} \mathrm{C}$ for the immobilized CA. These values are very close to those reported in the literature. ${ }^{36-38}$ For instance, as shown in Figure 9, Saferian et al. ${ }^{37}$ studied the molten globular-like state for $\mathrm{CA}$ in the presence of acetonitrile with various ratios and showed that the melting temperature decreased almost exponentially as the acetonitrile content was increased in the buffer solution. Here, the melting temperature of $58^{\circ} \mathrm{C}$ agreed very well with the reported data. Consequently, the immobilized CA would be more stable at lower temperatures, and it could be used in the biomimetic $\mathrm{CO}_{2}$ sequestration at temperatures less than $50^{\circ} \mathrm{C}$.

\section{Conclusion}

The $\mathrm{CA}$ is an important catalyst in biomimetic $\mathrm{CO}_{2}$ sequestration. However, there are disadvantages using free $\mathrm{CA}$ in $\mathrm{CO}_{2}$ sequestration. The free enzyme can lose its activity in solution in short times, the repeatable usage of the free CA won't be possible, and, the enzymes are expensive due to their purification costs. The enzymes need to be immobilized for their repeatable usage. There are various methods for enzyme immobilization, such as adsorption on surfaces, entrapment within matrices, or crosslinking within polymeric scaffolds; however, there are some disadvantages, such as detachment from surfaces as in adsorption, mass transfer limitations as in entrapment, and activity loss as in crosslinking. The CA was successfully immobilized within polyurethane foam, which was found to be a suitable support material for the CA immobilization because the PU was highly porous polymeric material, highly hydrophilic, and the enzyme immobilization was easy and fast. The immobilized CA showed an excellent reuse capacity and stable in aqueous solution. The ideal temperature of operation for immobilized CA was found to be $45^{\circ} \mathrm{C}$. When temperature was higher than $50^{\circ} \mathrm{C}$, the immobilized CA started to lose its activity, and totally inactive at $60^{\circ} \mathrm{C}$. Therefore, the immobilized $\mathrm{CA}$ could be used in the biomimetic $\mathrm{CO}_{2}$ sequestration at temperatures less than $50^{\circ} \mathrm{C}$.

\section{Acknowledgments}

The authors gratefully acknowledge the financial support of Izmir Institute of Technology through the project numbers 2006IYTE29 and 2008IYTE15, and Dow Chemicals, Turkey, for donating the HYPOL2060. 


\section{Literature Cited}

1. Tripp BC, Smith K, Ferry JG. Carbonic anhydrase: new insights for an ancient enzyme. J Biol Chem. 2001;276:48615-48618.

2. Whitney PL. Inhibition and modification of human carbonic anhydrase B with bromoacetate and iodoacetamide. Eur J Biochem. 1970;16:126-135.

3. Pocker Y, Stone JT. The catalytic versatility of erythrocyte carbonic anhydrase. VII. Kinetic studies of esterase activity and competitive inhibition by substrate analogs. Biochemistry. 1968; 7:3021-3031.

4. Innocenti A, Scozzafava A, Parkkila S, Puccetti L, Simone GD, Supuran CT. Investigation of the esterase, phosphate, and sulfatase activities of the cytosolic mammalian carbonic anhydrase isoform I, II and XIII with 4-nitrophenyl esters as substrates. Bioorg Med Chem Lett. 2008;18:2267-2271.

5. Supuran CT, Scozzafava A, Conway J. Carbonic Anhydrase. Its Inhibitors and Activators. New York: CRC Press, Vol. 1; 2004.

6. So AK, Espie GS, Williams EB, Shively JM, Heinhorst S, Cannon GC. A novel evolutionary lineage of carbonic anhydrase (epsilon class) is a component of the carboxysome shell. $J$ Bacteriol. 2004;186:623-630.

7. Cox EH, McLendon GL, Morel FM, Lane TW, Prince RC, Pickering IJ, George GN. The active site structure of Thalassiosira weissflogii carbonic anhydrase 1. Biochemistry. 2000;39: 12128-12130.

8. Esbaugh AJ, Tufts BL. The structure and function of carbonic anhydrase isozymes in the respiratory system of vertebrates. Respir Physiol Neurobiol. 2006;154:185-198.

9. Host G. Engineering carbonic anhydrase for highly selective ester hydrolysis. Ph.D. Dissertation, Linköping University, Sweden, Linköping, 2007.

10. Smith KS, Ferry JG. Prokaryotic carbonic anhydrases. FEMS Microbiol Rev. 2000;24:335-366.

11. Temperini C, Scozzafava A, Vullo D, Supuran CT. Carbonic anhydrase activators. Activation of isoforms I, II, IV, VA, VII, and XIV with L- and D-phenylalanine and crystallographic analysis of their adducts with isozyme II: stereospecific recognition within the active site of an enzyme and its consequences for the drug design. J Med Chem. 2006;49:3019-3027.

12. Hewett-Emmett D, Tashian RE. Functional diversity, conservation, and convergence in the evolution of the $\alpha-, \beta-$, and $\gamma$-carbonic anhydrase gene families. Mol Phylogenetic Evol. 1996;5:50-77.

13. Huang S, Xue Y, Sauer-Eriksson E, Chirica L, Lindskog S, Jansson B-H. Crystal structure of carbonic anhydrase from Neisseria gonorrhoeae and its complex with the inhibitor acetazolamide. J Mol Biol. 1998;283:301-310.

14. Christianson DW, Fierke CA. Carbonic anhydrase: evolution of the zinc binding site by nature and by design. Acc Chem Res. 1996;29:331-339.

15. Thorslund A, Lindskog S. Studies of the esterase activity and anion inhibition of bovine zinc and cobalt carbonic anhydrases. Eur J Biochem. 1967;3:117-123.

16. Drevon GF, Unbarke C, Russell AJ. Enzyme-containing Michaeladduct-based coatings. Biomacromolecules. 2003;4:675-682.

17. Duda DM, Tu C, Fisher SZ, An H, Yoshioka C, Govindasamy L, Laipis JL, McKenna MA, Silverman DN, McKenna R. Human carbonic anhydrase III: structural and kinetic study of catalysis and proton transfer. Biochemistry. 2005;44:1004610053.

18. Pocker Y, Stone JT. The catalytic versatility of erythrocyte carbonic anhydrase. III. Kinetic studies of the enzyme-catalyzed hydrolysis of p-nitropheny acetate. Biochemistry. 1967;6:668678.

19. Bond GM, Stringer J, Brandvold DK, Simsek FA, Medina MG, Egeland G. Development of integrated system for biomimetic $\mathrm{CO} 2$ sequestration using the enzyme carbonic anhydrase. Energy Fuels. 2001;15:309-316.
20. Mirjafari P, Asghari K, Mahinpey N. Investigating the application of enzyme carbonic anhydrase for $\mathrm{CO} 2$ sequestration purposes. Ind Eng Chem Res. 2007;46:921-926.

21. Liu N, Bond GM, Abel A, McPherson BJ, Stringer J. Biomimetic sequestration of $\mathrm{CO} 2$ in carbonate form: role of produced waters and other brines. Fuel Process Technol. 2005;86:16151625.

22. Jovica DB, Kostic NM. Effect of encapsulation in sol-gel silica glass on esterase activity, conformational stability, and unfolding of bovine carboniic anhydrase II. Chem Mater. 1999;11: 3671-3679.

23. Cheng L-H, Zhang L, Chen H-L, Gao C-J. Hollow fiber contained hydrogel-CA membrane contactor for carbon dioxide removal from the enclosed spaces. J Membr Sci. 2008;324:3343.

24. Hosseinkhani S, Nemat-Gorgani M. Partial unfolding of carbonic anhydrase provides a method for its immobilization on hydrophobic adsorbents and protects it against irreversible thermoinactivation. Enzyme Microb Technol. 2003;33:179-184.

25. Romaškevič T, Budrienè S, Pielichowski K, Pielichowski J. Application of polyurethane-based materials for immobilization of enzymes and cells: a review. Chemija. 2006;17:74-89.

26. Bakker M, Velde F, Rantwijk F, Sheldon RA. Highly efficient immobilization of glycosylated enzymes into polyurethane foams. Biotechnol Bioeng. 2000;70:342-348.

27. LeJeune KE, Mesiano AJ, Bower SB, Grimsley JK, Wild JR, Russell AJ. Dramatically stabilized phosphotriesterase-polymers for nerve agent degradation. Biotechnol Bioeng. 1997;54:105114.

28. LeJeune KE, Russell AJ. Covalent binding of a nerve agent hydrolyzing enzyme within polyurethane foams. Biotechnol Bioeng. 1996;51:450-457.

29. Wood LL. A hydrophilic polyurethane foam system. J Cell Plast. 1976;12:285-288.

30. Ozdemir E. Biomimetic $\mathrm{CO}_{2}$ sequestration: 1. Immobilization of carbonic anhydrase within polyurethane foam. Energy Fuels. 2009;23:5725-5730.

31. HYPOL. Laboratory Procedures and Foam Formulations, W.R. Grace \& Co.; pp 1-12.

32. Morrison RT, Boyd RN. Organic Chemistry, 4th ed. Boston: Allyn and Bacon, Inc.; 1959; p 1370.

33. Kjellsson A, Sethson I, Jansson B-H. Hydrogen exchange in a large $29 \mathrm{kD}$ protein and charecterization of molten globule aggregation by NMR. Biochemistry. 2003;42:363-374.

34. Shuler ML, Kargi F. Bioprocess Engineering, New York: Prentice Hall; 2002.

35. Pocker Y, Stone JT. The catalytic versatility of erythrocyte carbonic anhdrase. VIII. Deutterium solvent isotope effects and apparent activation parameters for the enzyme-catalyzed hydrolysis of p-nitrophenyl acetate. Biochemistry. 1968;7:4139-4145.

36. Jiang Y, Su JT, Zhang J, Wei X, Yan Y-B, Zhou H-M. Reshaping the folding energy landscape of human carbonic anhydrase II by a single point genetic mutation Pro23His. Int $J$ Biochem Cell Biol. 2008;40:776-788.

37. Safarian S, Saffarzadeh M, Zargar SJ, Moosavi-Movahedi AA. Molten globule-like state of bovine carbonic anhydrase in the presence of acetonitrile. J Biochem. 2006;139:1025-1033.

38. Lavecchia R, Zugaro M. Thermal-denaturation of erythrocyte carbonic-anhydrase. FEBS Lett. 1991;292:162-164.

39. Salami Z, Hosseinkhani S, Ranjbar B, Nemat-Gorgani M. Interaction of native and apo-carbonic anhydrase with hydrophobic adsorbents: a comparative structure-function study. J Biochem Mol Biol. 2006;39:636-641.

40. Azari F, Nemat-Gorgani M. Reversible denaturation of carbonic anhydrase provides a method for its adsorptive immobilization. Biotechnol Bioeng. 1999;62:193-199.

Manuscript received Jan. 18, 2010, and revision received Apr. 2, 2010. 